\title{
Article \\ Application and Significance of Geological, Geochemical, and Geophysical Methods in the Nanpo Gold Field in Laos
}

\author{
Jie Gan ${ }^{1,2}{ }^{-}$, Hui Li ${ }^{1,2, *}$, Zhengwei He ${ }^{1,2, *}$, Yu Gan ${ }^{3}$, Junqing Mu ${ }^{3}$, Huan Liu ${ }^{3}$ and Lin Wang ${ }^{3}$ \\ 1 Key Laboratory of Tectonic Controls on Mineralization and Hydrocarbon Accumulation, Chengdu University \\ of Technology, Chengdu 610059, China; ganjie@stu.cdut.edu.cn \\ 2 College of Earth Science, Chengdu University of Technology, Chengdu 610059, China \\ 3403 Geological Team of the Bureau of Geological and Mineral Resources of Sichuan, Emeishan 614200, China; \\ 13990657092@163.com (Y.G.); 15928726984@163.com (J.M.); 17761267653@163.com (H.L.); \\ 18227617653@163.com (L.W.) \\ * Correspondence: lihui@stu.cdut.edu.cn (H.L.); hzw@cdut.edu.cn (Z.H.)
}

\section{check for} updates

Citation: Gan, J.; Li, H.; He, Z.; Gan, Y.; Mu, J.; Liu, H.; Wang, L. Application and Significance of Geological, Geochemical, and Geophysical Methods in the Nanpo Gold Field in Laos. Minerals 2022, 12, 96. https://doi.org/10.3390/ $\min 12010096$

Academic Editors: António Manuel Nunes Mateus, Huan Li and Han Zheng

Received: 21 December 2021

Accepted: 12 January 2022

Published: 14 January 2022

Publisher's Note: MDPI stays neutral with regard to jurisdictional claims in published maps and institutional affiliations.

Copyright: (c) 2022 by the authors. Licensee MDPI, Basel, Switzerland. This article is an open access article distributed under the terms and conditions of the Creative Commons Attribution (CC BY) license (https:/ / creativecommons.org/licenses/by/ $4.0 /)$.

\begin{abstract}
As the main part of the Indosinian metallogenic province in the eastern part of the Tethys metallogenic domain, Southeast Asia has experienced multiple stages of tectonic magnetic activities accompanied by the formation of rich mineral resources. However, due to the undeveloped economy, low degree of geological work, dense vegetation cover, and lack of obvious prospecting marks, traditional geological prospecting work in the area is not optimal. Consequently, the combination of high-precision geophysics and geochemistry has become an important method of looking for ore bodies deep underground in this area. The Nanpo gold deposit is a hydrothermal gold deposit that occurs in the Indosinian felsic volcanic rock body, and its mineralization is closely related to felsic magmatism. This study carried out comprehensive geophysical and geochemical exploration methods of soil geochemical survey, induced polarization (IP) survey, and audio-frequency magnetotelluric (AMT) survey. Based on the characteristics of geophysical and geochemical anomalies, geological inference, and interpretation, the integrated geophysical and geochemical prospecting criteria of the ore area have been determined: The large-scale and overlapping Au-Ag-Cu anomaly area in the host felsic magmatic rocks (mainly diorite, monzodiorite and granodiorite) is a favorable metallogenic area. Two anomalies, $\mathrm{P} 1-\mathrm{H} 1$ and $\mathrm{P} 3-\mathrm{H} 6$, with the best metallogenetic conditions and the deepest extensions of the known ore bodies, were further selected as engineering verification targets. After the study of the drill core, gold (mineralized) bodies consistent with the anomalies were found, indicating that the combined method is suitable for the exploration of mineral resources in this area, and the prospecting effect is good. At the same time, the metallogenic prediction shows that the deep part of the mining area still has great metallogenic prospects and prospecting potential. The characteristics of geophysical and geochemical anomalies and prospecting experience in the study area can provide references for the prospecting of hydrothermal gold deposits in the Luang Prabang-Loei structural belt.
\end{abstract}

Keywords: gold deposition; geophysical and geochemical abnormalities; magmatism; metallogeny; Laos

\section{Introduction}

Over a long geological history of evolution, many different types of tectonic movements have taken place in Southeast Asia, forming various types and multi-stage magmatic superimposed magmatic tectonic belts. At the same time, there are more endogenetic metal deposits, such as copper and gold, that include porphyry-type copper-gold deposits, porphyry-skarn-type copper-gold deposits, and low-temperature hydrothermal-type gold deposits [1-13]. Due to the underdeveloped economy of Laos and the lack of professional geological survey teams, the existing geological work in this area is low [14-18]. In addition, the complex natural conditions in the area, including extremely developed tropical rain 
forest, a few rock outcrops, strong weathering and inconvenient transportation in the forest area, greatly increase the difficulty of mineral exploration [19-25]. For these reasons, the traditional geological mapping or soil geochemical methods cannot be used to locate deep and concealed ore (mineralized) bodies alone. Therefore, the prospecting work in this area can use the method of soil geochemical survey supplemented by geophysical survey.

The Nanpo gold deposit studied in this study is a new large to super-large gold deposit discovered recently in the south middle section of the Luang Prabang-Loei structural belt. The gold (mineralized) bodies mainly occur in Indosinian felsic magmatic rock (mainly diorite, monzodiorite, and granodiorite). The research shows that gold from the Nanpo gold mine mainly carries the mineral metal sulfide (pyrite), which is a good benign conductor. There are obvious physical differences in the properties between the Nanpo gold mine and the surrounding rock without ore. Therefore, the ore (mineralized) bodies can be located by the induced polarization (IP) method and the audio-frequency magnetotelluric (AMT) method.

Soil geochemical surveys can analyze the relationship between the distribution of elements and geological bodies so as to delineate the areas of geochemical anomaly. By measuring the resistivity and amplitude frequency of underground materials, induced polarization surveys can delineate abnormal areas with low resistivity and high amplitude frequency, which may be potential mineralized areas. Audio-frequency magnetotelluric (AMT) surveys can infer the spatial distribution of ore (mineralized) bodies and judge the deep development of ore controlling structures [26-29]. Based on the characteristics of geophysical and geochemical anomalies, we can delineate the favorable metallogenic area, explore the deep prospecting potential of the mining area, and provide a geophysical basis for deep prospecting engineering. However, the current understanding of the deposit is not sufficient to restrict the genesis of the deposit and the relationship between geophysical and geochemical anomalies and the regional structure and magmatic metallogenic process. Based on the regional tectonic magmatic evolution and metallogenic background, the metallogenic information of the Nanpo gold deposit is studied using complete prospecting and exploration methods. The results of this research may provide guidance and references for mineral exploration and further investigation of related deposits in the south-midsection of the Luang Prabang-Loei tectonic belt.

\section{Geological Setting}

\subsection{Regional Geology}

The region of Southeast Asia is geographically situated at the intersection of the eastern segment of the tectonic domain of Tethys and the tectonic domain of the Western Pacific (Figure 1a). In the long process of geological evolution, this area experienced the subduction, collision, and accretionary orogeny of the Paleotethys Ocean from the Late Paleozoic to the Mesozoic, coupled with multiple stages of tectonic magmatic activities [30-38]. Based on the distribution and development of regional tectonics and their spatio-temporal properties, the research area was divided into seven tectonic units of the third order from west to east (Figure 1b); the study area was distributed in the Luang Prabang-Loei volcanic arc zone on the southeast margin of Simao-Phitsanulok block, which is nearly parallel to Dian Bien Phu-Loei suture zone in the east. Paleozoic strata in the volcanic arc belt are mainly composed of neritic-littoral volcanic rocks and sedimentary rocks, and the main lithology exposed is sandstone, sandstone, and shale, accompanied by siliceous and ferromagnetic extrusive rocks of subvolcanic rocks. Mesozoic strata are composed of continental marine clastic rocks (sandstone, mudstone, calcareous, and schist). The Cenozoic strata are mainly made up of representatives of silty mudstone, sandy silty mudstone, and quartz greywacke, intercalated with off-white and greyish-green gypsum salt layers with certain sedimentary rhythm and locally containing marl or lignite $[39,40]$. 


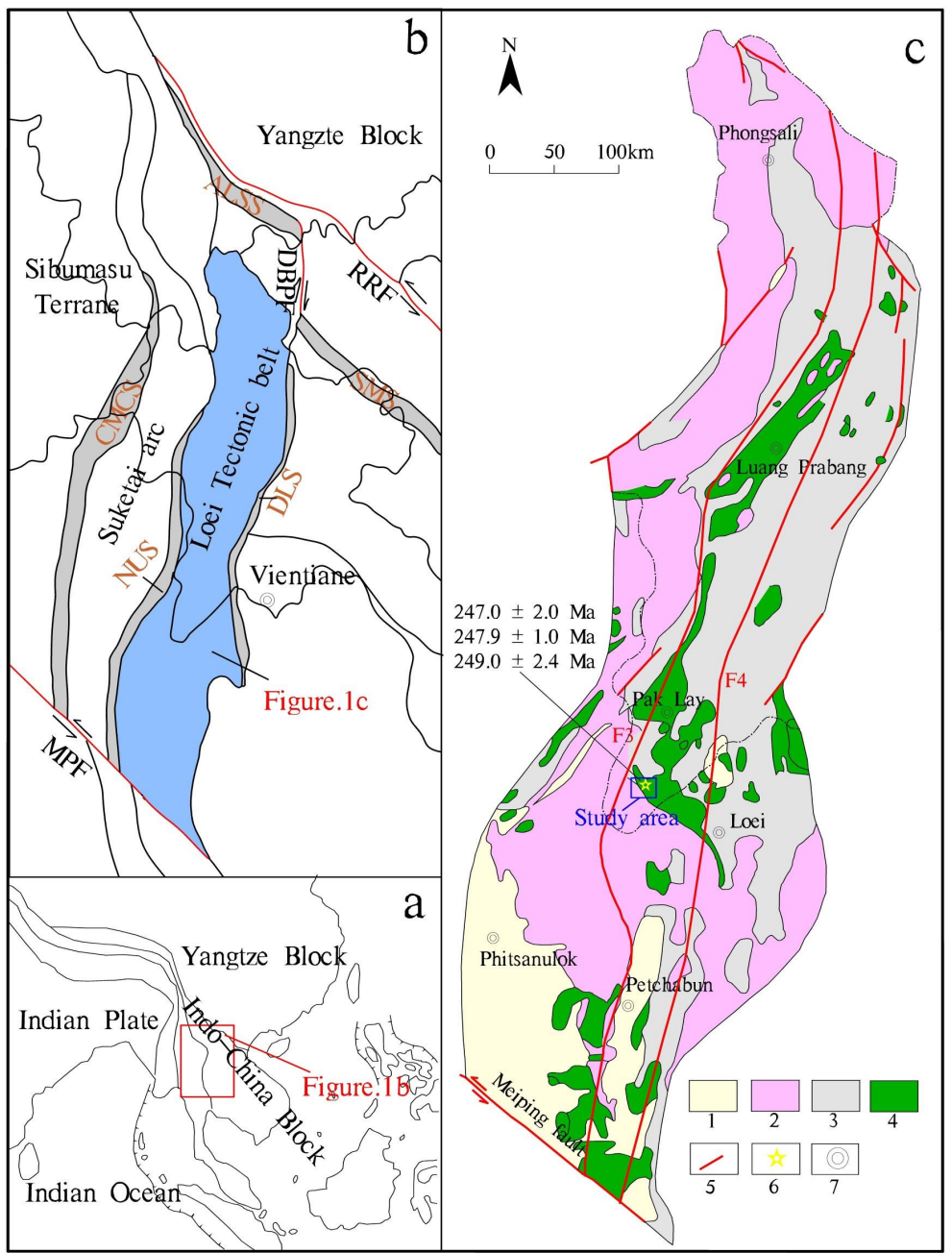

Figure 1. (a,b) Subdivisions of the location of the Luang Prabang-Loei structural belt and the division of Indosinian plate tectonic units; (c) subdivisions of the geological and mineral distribution of Luang Prabang-Loei metallogenic belt (modified from [16,39,41,42]) 1. Quaternary; 2. Mesozoic clastic rocks, shales, marls, etc.; 3. Late Paleozoic sandstones, shales and epimetamorphic rocks; 4 . volcanic rocks; 5. faults; 6. Nanpo gold deposits; 7. cities. MPF:Meiping fault, RRF:Red River fault, DBPF: Dian Bien Phu fault, DLS: Dian Bien Phu-Loei suture, NUS: Nan-Uttaradit suture, SMS: Song-Ma suture, CMCS: Changning-Menglian-Chieng Mai suture, ALSS: Ailaoshan suture.

The magmatic activity in the Luang Prabang-Loei tectonic belt is strong, and a series of island arc magmatic rocks are developed from basic (basalt), neutral (andesite) to acid (rhyolite). Zircon U-Pb age (248 Ma) from felsic volcanic rocks exhibited in the area of the Nanpo gold deposit belongs to the earliest Triassic. At the same time, combined with the analysis of the major trace elements and rare earth elements in the rocks, the properties of island arc magmatic rocks are revealed (detailed data are published separately). The analysis of regional tectonic evolution indicates that the study area was at an island arc environment of oceanic subduction in the Early Triassic, and the mineralization may be related to the arc volcanic magma formed by the eastward subduction of the Paleo-Tethys Ocean.

The gold deposit Nanpo is situated in the region of Sanakham in the south-central part of the arc of the island of Luang Prabang-Loei (Figure 1b,c). Under the control of the Luang Prabang fault (F3) and the Preshan fault (F4) of the regional super-lithosphere, the overall structure of the region is characterized by a broad and gentle compound fold and fault dominated by the NNE direction, and the second is nearly NS and NNW folds/faults and nearly EW secondary faults. The two boundary flaws above are major structures controlling 
the overall structural framework and mineral distribution in the region including the Nanpo gold deposit area.

\subsection{Gold Deposits and Characteristics of Ore Bodies}

Through geological mapping, it was found that the deposit is primarily late carboniferous (C3) nestetic-shoreline facies sedimentary rocks that are covered by a Quaternary alluvial slope (residual) layer. The outcropping lithology of the Nanpo deposit area is mainly variegated sedimentary fine clastic rocks (sandstone/shale), light metamorphic rocks (sandstone slate/carbonaceous slate), and felsic volcanic rocks (diorite, monzodiorite, and granodiorite) emplaced in the upper Carboniferous.

The deposit district is situated near the core of the west wing of the H. KHANPOUNGLAK Syncline. Regional strata are typically monocline strata strongly tended to the west, and the angle of dip is locally gentle due to the influence of the faults. The structures are well developed in the deposit district under the impact of regional translithospheric Luang Prabang fault and Poleyshan fault. The structural features are mainly characterized by faults, joint fissures, breccia zones, corrugation, flexure, brittle-ductile shear fracture alteration zones, etc.

Ore (mineralized) bodies of the Nanpo gold deposit mainly occur in the Indosinian felsic magmatic rock body, which is closely related to the structural fissure dense zone and appear as irregular monophyletic and lenticular. Ore (mineralized) bodies are distributed in NE-SW direction, and the ore veins are strictly controlled by a group of shear joints and fracture dense zones gently inclining to the southeast. The width of the controlled mineralization area within the mining area is $935-1784 \mathrm{~m}$, and the length of the strike is approximately $3058 \mathrm{~m}$. Gold-bearing minerals in the deposit district are mainly pyrite and limonite, and the types of metal sulfides in the mining area are simple, mainly pyrite, trace chalcopyrite, occasionally galena, and sphalerite. The type of ore processor is low sulfur gold ore, and the quality of the ore is mainly low-grade gold ore, followed by medium- and high-grade ore, on average, Au $4.22 \mathrm{~g} / \mathrm{t}$.

In addition to regional metamorphism (greenschist facies), rocks in the district also have obvious thermal contact metamorphism characteristics. A large and irregular alteration halo formed around the southern diorite-monzonite rock mass and shows the phenomenon of area zoning centered on the rock mass. This reflects the obvious relationship between wall rock alteration and faults, showing a trend of decreasing intensity from the fault and mineralization center outwards and belongs to the type of extremely lowpressure contact metamorphism. In addition, alteration phenomena, such as fine-net-vein carbonation (partially quartz veins) and limonite-pyrite mineralization along the cracks in the middle and late rock formations, are also common. Especially in the vicinity of fault structures and in the fracture zone, the pyritization is along with the fractures, light yellow allomorphic, subhedral to euhedral (mainly cubic) fine to medium granular, with fine to reticular veins, irregular clumps, and veins of different thicknesses, often accompanied by strong silicification.

\section{Sampling and Methods}

In the geological and mineral exploration work in the study area, through the use of geology, geophysics, geochemistry, and other multidisciplinary, comprehensive research methods, the geological characteristics and genesis of the ore deposits in the area have been studied in depth, and better exploration results have been obtained.

\subsection{Sampling}

In this soil geochemical survey, a total of $34 \mathrm{~km}^{2}$ of field scanning was completed, and 8690 soil samples were collected including 445 duplicate samples. The samples were mainly taken from the fine-grained materials in the soil of layer B (eluvial layer) or layer $\mathrm{C}$ (parent material layer) on the surface, mainly composed of fine-grained clay, loam, and sandy soil. Before the induced polarization survey and audio-frequency magnetotelluric 
(AMT) survey, we collected 6 kinds of main exposed rock (ore) samples (104 in total) in the mining area and measured the electrical parameters by the forced current method (Table 1).

Table 1. Electrical parameters of rock (ore) samples.

\begin{tabular}{cccccc}
\hline \multirow{2}{*}{ Lithology } & Number & \multicolumn{2}{c}{$\mathbf{F}_{\mathbf{s}}(\mathbf{\%})$} & \multicolumn{2}{c}{$\rho_{\mathbf{s}}(\mathbf{\Omega} \cdot \mathbf{m})$} \\
\cline { 2 - 6 } & 25 & $0.00-9.13$ & 0.75 & $88-2340$ & 306 \\
\hline Silty slate & 9 & $0.33-36.18$ & 12.25 & $52-2919$ & 603 \\
\hline Pyritized diorite & 12 & $2.25-27.67$ & 18.91 & $3-308$ & 7 \\
\hline Pyrite & 26 & $0.24-5.25$ & 1.06 & $1443-25,764$ & 3431 \\
\hline Gabbro & 22 & $0.44-2.15$ & 1.24 & $692-8448$ & 2945 \\
\hline Diorite & 10 & $2.67-31.28$ & 18.34 & $191-2038$ & 756 \\
\hline Pyritized sand slate & & & $\begin{array}{c}\text { Average } \\
\text { Value }\end{array}$ & $\begin{array}{c}\text { Range of } \\
\text { Value }\end{array}$ \\
\hline
\end{tabular}

\subsection{Methods}

This work was based on a 1:5000 base map, and the soil geochemical survey points and induced polarization points were arranged on the topographic map according to the strike perpendicular to the stratum (orebody) at a grid spacing of $100 \mathrm{~m} \times 40 \mathrm{~m}$ and $80 \mathrm{~m} \times$ $20 \mathrm{~m}$ (Figure 2). Transformation parameters were corrected by an independent coordinate system, and the survey points were positioned by hand-held GPS, the GPS system was UTM, and the map reference was WGS84.

The soil geochemical survey took the GPS survey point as the center, radiated 3-5 sampling points around within $100 \mathrm{~m}^{2}$, and equally combined them into a mixed sample. The sampling depth was $20-50 \mathrm{~cm}$ below the surface, and $0.6-1.0 \mathrm{~kg}$ of soil without humus and stones was taken. The collected samples were sent to the laboratory for analysis in strict accordance with the procedures of drying $\rightarrow$ beating $\rightarrow$ passing through a 60 mesh screen $\rightarrow$ mixing and compression $\rightarrow$ loading into a paper bag $\rightarrow$ packing and storage. The weight of samples sent for inspection were greater than $150 \mathrm{~g}$ under the condition of preventing sample pollution. The test and analysis of samples were completed at the Chengdu test center. Au and Ag were analyzed by graphite furnace atomic absorption spectrometry, analysis of $\mathrm{Cu}$ by flame atomic absorption spectrometry, and determination of $\mathrm{As}, \mathrm{Sb}$, and $\mathrm{Hg}$ by atomic fluorescence spectrometry.

Induced polarization measurement was carried out with an intermediate gradient device $(\mathrm{AB}=1200 \mathrm{~m} ; \mathrm{Mn}=40 \mathrm{~m})$, and the SQ-3C dual-frequency IP instrument (including transmitter and receiver) developed by Central South University was used. The transmitter synthesizes the high- and low-frequency current ( 4 and $4 / 13 \mathrm{H}_{\mathrm{Z}}$ in this study) into the dual-frequency current, and the receiver receives the response of the underground target to the dual-frequency current and, at the same time $(\Delta \mathrm{VH}, \Delta \mathrm{VL})$, measures the response potential difference of the two frequencies and calculates the apparent amplitude frequency, $\mathrm{F}_{\mathrm{S}}$, and apparent resistivity, $\rho_{\mathrm{S}}$, with Formula (1) and Formula (2), respectively.

$$
\begin{gathered}
F_{s}=\frac{\Delta V L-\Delta V H}{\Delta V H} \times 100 \% \\
\rho_{s}=k \frac{\Delta V}{I}
\end{gathered}
$$

Audio-frequency magnetotelluric (AMT) survey used the V8 multi-function electrical method workstation of the Phoenix company of Canada for observation. The $6 \mathrm{R}$ mainframe box adopted a four channel layout (i.e., Hx, Hy, Ex, and Ey), and the RXU-3ER auxiliary box adopted a two channel layout (i.e., Ex and Ey). The 111 and 191 exploration lines were selected for measurement (point distance was $50 \mathrm{~m}$, and electrode distance was $40 \mathrm{~m}$ ). The 
"ten" typical pole distribution method was adopted. The acquisition frequency band was $10,000-0.00005 \mathrm{~Hz}$, and the observation time on a single point as not less than $40 \mathrm{~min}$.

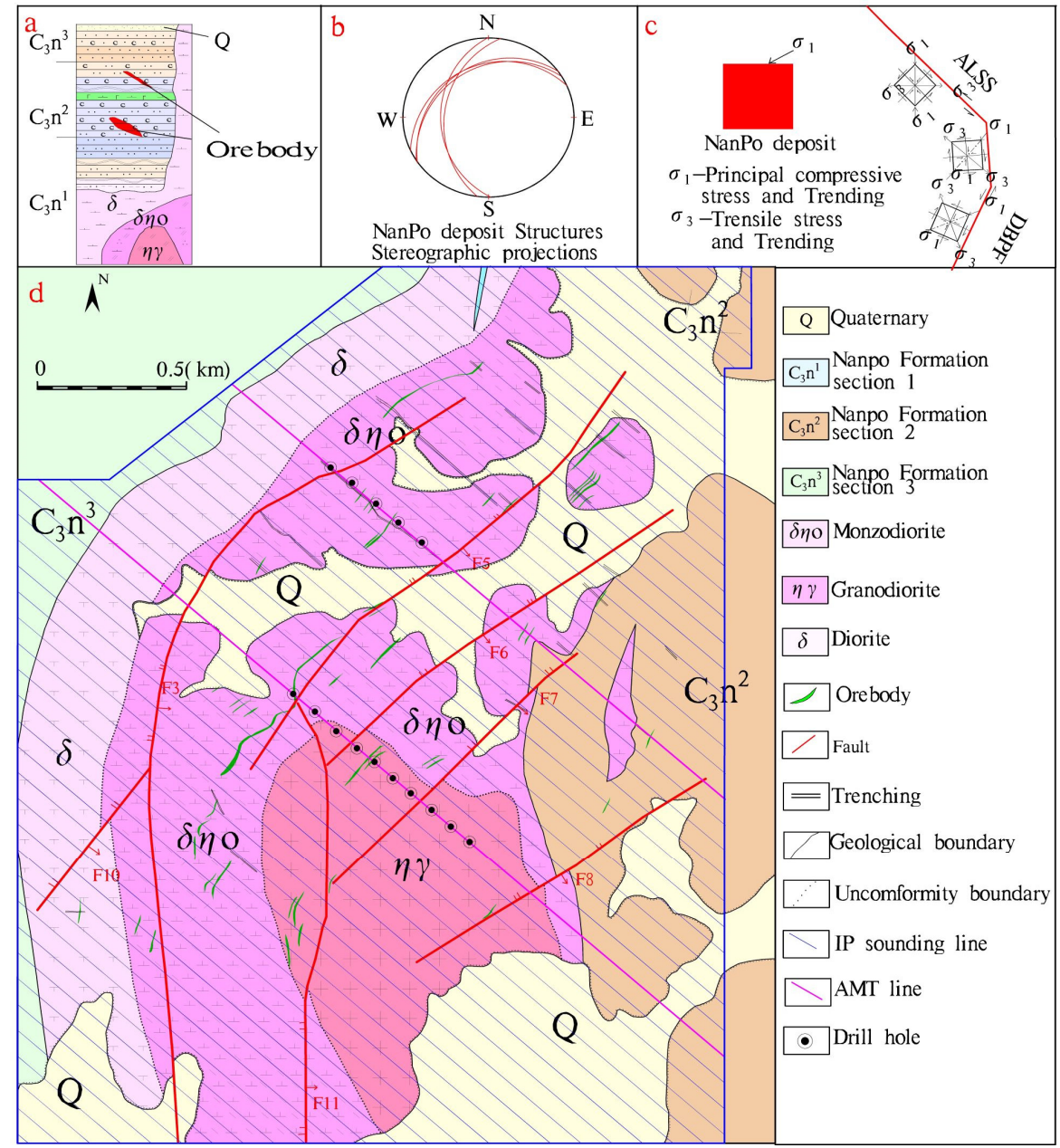

Figure 2. (a) Depositional sequence; (b) structural orthographic projection of the Nanpo deposit (S hammer sphere, equal area); (c) regional tectonic stress analysis sketch; (d) geological map of the Nanpo deposit district. ALSS: Ailaoshan suture, DBPF: Dian Bien Phu fault.

\section{Results}

\subsection{Soil Geochemical Survey Results}

In geochemical prospecting, element combination can reflect the spatial distribution of elements. According to the average value $(X)$ and deviation $(S)$ of each element obtained from data processing, the anomaly lower limit of each element was calculated according to $X+2 S$, and then a reasonable lower limit of anomalies was determined based on the geological background of the study area (Table 2). On the basis of each single element anomaly, the main metallogenic element and indicator element anomalies closely associated in space and with genetic connection were merged into a comprehensive anomaly. The soil geochemical survey had obvious concentration center, and the zonal center in many comprehensive anomalies delineated in the metallogenic favorable areas, such as orehosting strata and ore-controlling structures, and the abnormal area was large and the scale was good. The element combination was mainly $\mathrm{Au}-\mathrm{Ag}-\mathrm{Cu}$ with high content, and the overlap of $\mathrm{Au}-\mathrm{Ag}-\mathrm{Cu}$ was also good at the core of the maximum concentration (Figure 3). 
Table 2. The lower limit of the soil geochemical investigation in the Nanpo gold deposit.

\begin{tabular}{ccccc}
\hline Element & $\begin{array}{c}\text { Average Value } \\
(\mathbf{X})\end{array}$ & Deviation (S) & $\begin{array}{c}\text { Calculated } \\
\text { Value }\end{array}$ & Actual Value \\
\hline $\mathrm{Au}$ & 4.90 & 4.53 & 13.96 & 15 \\
\hline $\mathrm{Ag}$ & 0.09 & 0.04 & 0.17 & 0.15 \\
\hline $\mathrm{Cu}$ & 33.69 & 12.53 & 58.25 & 60 \\
\hline $\mathrm{As}$ & 8.42 & 4.84 & 18.1 & 20 \\
\hline $\mathrm{Sb}$ & 0.50 & 0.22 & 0.93 & 1 \\
\hline $\mathrm{Hg}$ & 0.03 & 0.01 & 0.05 & 0.05 \\
\hline
\end{tabular}

$\mathrm{F}_{\mathrm{s}}$-Amplitude frequency; $\rho_{\mathrm{s}}$-apparent resistivity. Calculation formula of abnormal lower limit: $\mathrm{Ca}=\mathrm{X}+2 \mathrm{~S}$.

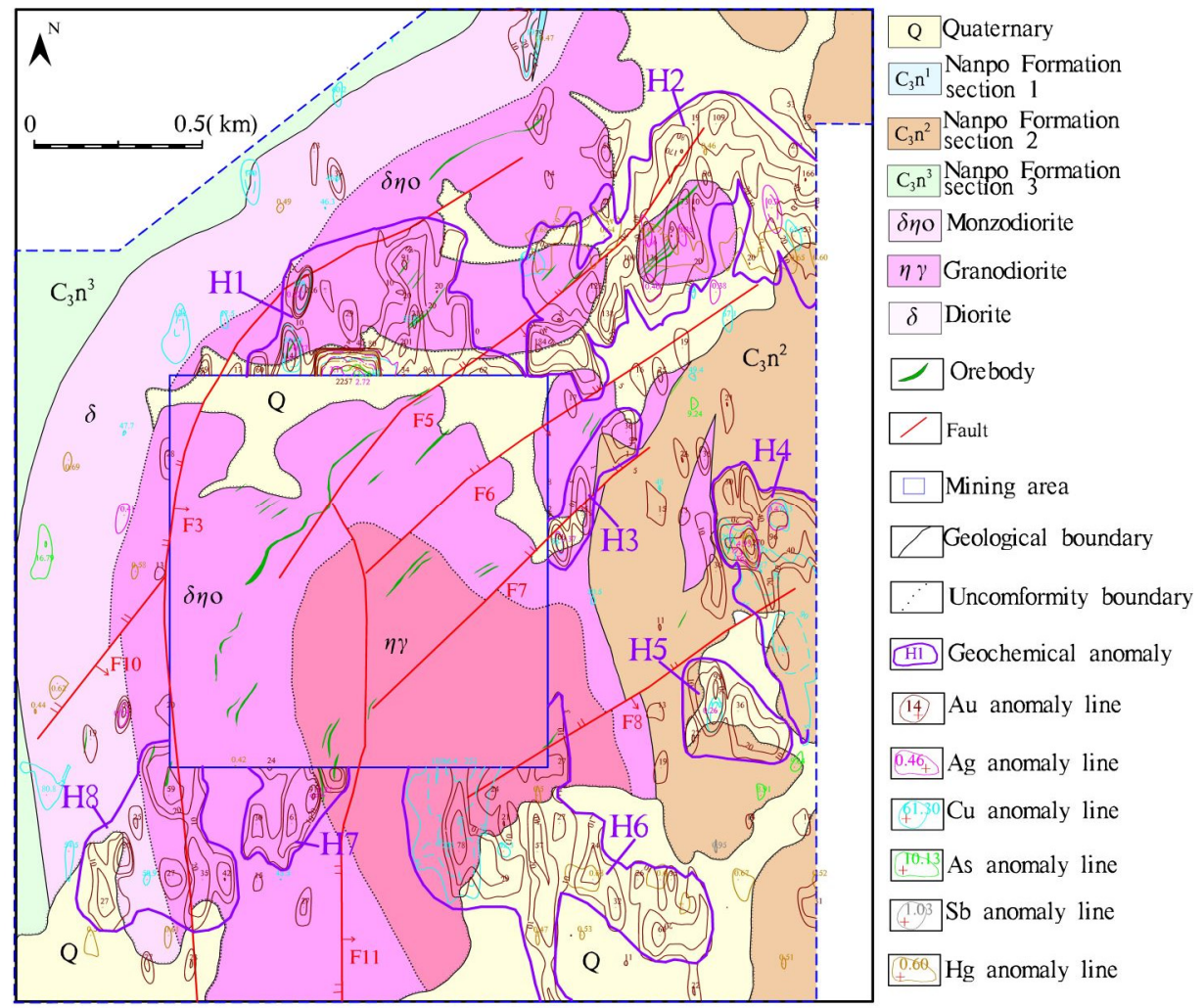

Figure 3. Comprehensive geochemical anomaly map of the soil in the Nanpo gold deposit.

Based on the comprehensive analysis of the element geochemical characteristics, element combinations and anomalous spatial correlation, mineralization geological conditions, and known mineral distribution, it was concluded that the $\mathrm{H} 1, \mathrm{H} 4$, and $\mathrm{H} 6$ anomalies delineated by this soil geochemical survey may be the best anomalies (Figure 3). They were distributed around the mining area, the anomalous areas were large and scaled, and the mining area was in the NE-SW direction along with the intermediate acid magmatic body plane zonal distribution. At the same time, they all had obvious concentration centers and zonation centers, and most of the high and extreme values of Au were located near faults. It is speculated that along the $\mathrm{H} 1, \mathrm{H} 4$, and $\mathrm{H} 6$ anomalies in the NE-SW direction, there is a wide and continuously distributed concealed geological body (Figure 3) that may be a deep gold orebody. 


\subsection{Induced Polarization Geophysical Results}

Ore in the Nanpo gold deposit (pyrite and pyritized magmatic rocks) had a higher apparent amplitude frequency $\left(\mathrm{F}_{\mathrm{s}}\right)$ with an average value of $12.25-18.91 \%$, and the apparent resistivity $\left(\rho_{\mathrm{s}}\right)$ was lower with an average value of $7-603 \Omega \cdot \mathrm{m}$. This mainly shows the characteristics of low resistance and high polarization. However, the apparent amplitude frequency $\left(\mathrm{F}_{\mathrm{S}}\right)$ of the surrounding rock without ore was lower, generally less than $1.2 \%$, and the apparent resistivity was higher with an average value of more than $1000 \Omega \cdot \mathrm{m}$. The statistical results show that there were obvious differences in the physical properties between mineralized bodies and the surrounding rocks in the study area, which is a prerequisite for geophysical exploration.

Depending on the IP measurement anomaly map (Figure 4), the eastern, western, and northern edges of the mining area showed obvious electrical characteristics of low resistance and high amplitude frequency, and the central part showed electrical characteristics of medium-high resistance and low amplitude frequency, which is basically consistent with the geological characteristics that the central part is mainly magmatic rock, and the eastern, western, and northern edges are sandstone slate. Previous research results show that ore bodies mainly hosted in magmatic rocks, while the target ore bodies (i.e., pyrite and pyritized magmatic rocks) in this exploration were mainly characterized by medium, low resistance, and high amplitude frequency. Therefore, in combination with geological characteristics, abnormal form and scale, we determined that the lower limit of the amplitude frequency delineated by IP anomaly was $\mathrm{F}_{\mathrm{S}}=2.4 \%$, and six IP anomalies (P1 P6) were delineated in the middle- and high-resistance area (magmatic body).
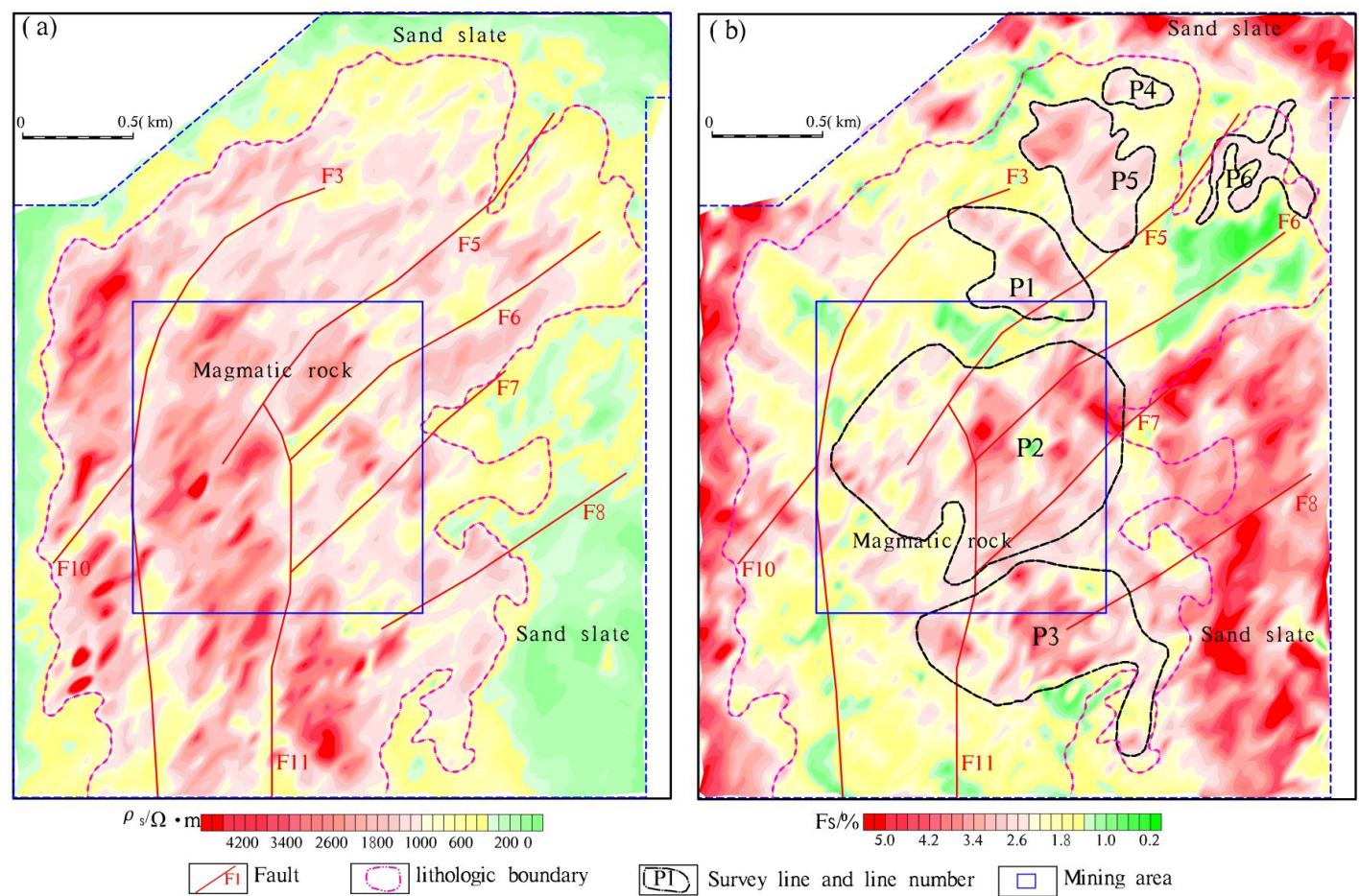

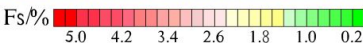

Fi Fault lithologic boundary

(PI) Survey line and line number $\square$ Mining area

Figure 4. Induced polarization (IP) anomaly diagram of the Nanpo gold deposit: (a) resistivity; (b) amplitude frequency.

The P2 anomaly area is located in the current mining area, corresponding to the known orebody (mineralization). P1 and P3 are located in the north and south sides of the mining area. These anomalies are mainly exposed in the Indosinian felsic magnetic body. Silicification, carbonation, chloritization, epidotization, and potassium feldsparization usually occur in the surrounding rocks. The fault structural belt mainly passes through these abnormal areas in the NE-SW direction. The P1 abnormal area mainly passes through 
the F3 and F5 faults, the P2 abnormal area mainly passes through the F6 and F7 faults, and the P3 abnormal area mainly passes through the F8 faults (Figure 5). Since the P2 anomaly area was caused by known orebody (mineralization), and the P1 and P3 anomaly areas had similar faults, such as the P2 anomaly area, and corresponded well with the H1 and H6 anomalies delineated by geochemical exploration, it is speculated that P1 and P3 may also be caused by orebodies (mineralization) or altered mineralization zone. Two AMT survey lines (Figure $2 \mathrm{~d}$ ) were preferentially arranged to detect whether there are geological bodies with low resistivity and high amplitude frequency under the P1-P2 anomaly.
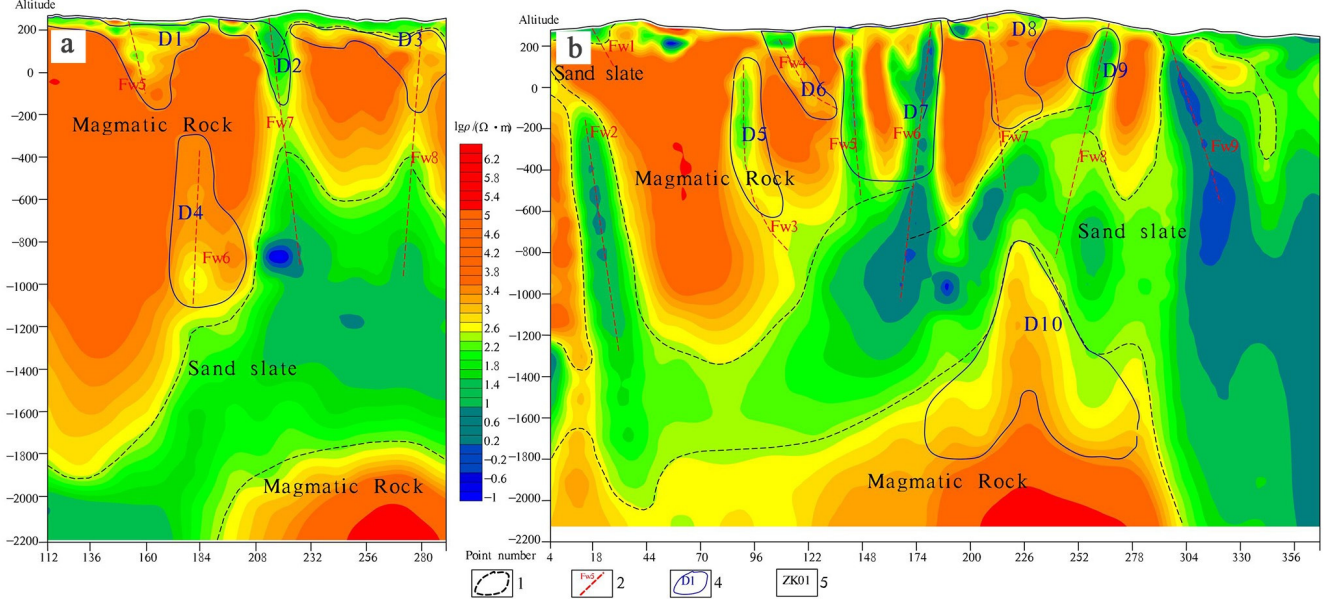

Figure 5. (a) 111 line profile inference diagram; (b) 191 line profile inference map.

\subsection{Audio-Frequency Magnetotelluric (AMT) Survey Results}

According to the AMT inversion resistivity section map (Figure 5), the location and boundary of magmatic rock and sandstone slate were basically delineated in the vertical direction, and 10 favorable mineralization areas (D1-D10) were speculated in the local low-resistivity anomaly area of deep high-resistivity anomaly, with an apparent amplitude frequency value greater than $2.4 \%$. In the horizontal direction, nine faults (Fw1-Fw9) were successively inferred in the low-resistivity abnormal area of banded resistivity isolines, which are discontinuous, abrupt, trap, or semi-trap.

Comparing and analyzing the audio-frequency magnetotelluric survey results of line 111 and line 191 (Figure 6), it was found that the delineated magmatic body (highresistivity body) was distributed stably along the $\mathrm{N}-\mathrm{S}$ direction, its bottom interface had good continuity, and it was characterized by shallow east and deep west on the whole, and the low-resistivity anomaly area distributed continuously along the N-S direction, and the shape was basically the same. Thus, the ore-forming benefits delineated by the AMT were divided into three obvious metallogenic favorable zones, numbered: I, II, and III, respectively. Among them, the metallogenic favorable areas corresponding to I were D1, D4, and D7; the metallogenic favorable areas corresponding to II were D2 and D8; the metallogenic favorable areas corresponding to III were D3 and D9. At the same time, obvious high-resistivity bodies were found in the depth of the two survey lines (below $-1800 \mathrm{~m}$ ), which indicates that there may be a huge concealed magmatic body spreading along the $\mathrm{N}-\mathrm{S}$ direction in the depth of the study area, and there also has a good prospecting foreground. The predicted faults were also quite consistent with the apparent resistivity contour lines of the IP intermediate gradient scanning, which proves the reliability of AMT measurement. These faults control the intrusion of the main magmatic body and the large geological boundary of the mining area as a whole and have good continuity along the $\mathrm{N}-\mathrm{S}$ direction. They are considered to be the channels of the deep magmatic hydrothermal invasion, and it is speculated that these faults are the ore-guiding and ore-hosting structures of the ore deposit. 


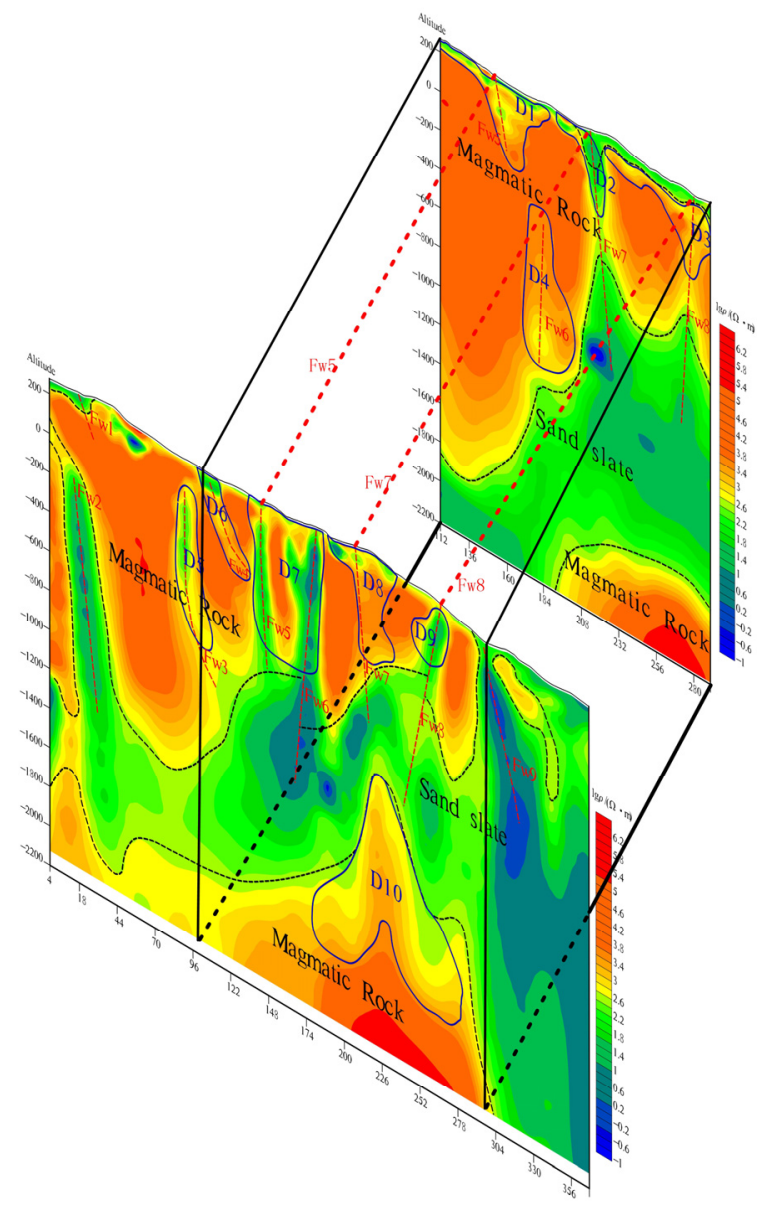

Figure 6. Comparison diagram of AMT comprehensive profile.

\section{Metallogenic Prediction Ore Prospecting Targets and Confirmation Results}

\subsection{Ore Prospecting Targets}

The IP geophysical anomalies and soil geochemical anomalies (P1-H1 and P3-H6) coincided with each other in the study area. The NE-SW trending faults were developed in the study area, and the stratigraphic and lithologic conditions were good. The $\mathrm{Au}, \mathrm{Ag}, \mathrm{Cu}$, and other ore-forming elements related to hydrothermal sulfide were mainly enriched in the felsic magmatic rock. The audio-frequency geodesy results also showed that there was a huge hidden magmatic rock mass spreading N-S in the deep, which has a good prospecting foreground. Meanwhile, surface trough exploration and shallow drilling projects found corresponding orebody (mineralization) and mineralized alteration zones near the P1-H1 anomaly (Figures 3 and 5). It was shown that IP geophysics, soil geochemical survey, and audio geodesy are suitable for exploration in this area. At the same time, the high consistency of surface chemical anomalies and IP measurement anomalies provide a reliable basis for further exploration and verification.

According to the geological characteristics, IP geophysical and soil geochemical anomalies, and audio-frequency geodesy results of the Nanpo gold deposit, the prospecting target area was determined, especially the deep extension part of the current mining area, and the deep part of the $\mathrm{N}-\mathrm{S}$ extension overlapping anomalies (P1-H1 and $\mathrm{P} 3-\mathrm{H} 6)$ area, and there may be industrial-grade concealed orebody (mineralization).

\subsection{Prospect Confirmation Results}

Through comparative analysis of the IP geophysical and soil geochemical anomaly areas, it was found that two anomaly areas, P1-H1 and P3-H6, with good overlap were in good agreement with the existing geological and metallogenic conditions, and they 
are obvious targets verified by trenching and drilling engineering. In the No. 5 orebody found in the P1-H1 abnormal area, the controlled strike length of the gold orebody was approximately $200 \mathrm{~m}$, the dip length was $350 \mathrm{~m}$, the average thickness was $1.37 \mathrm{~m}$, and the average grade of $\mathrm{Au}$ was $2.75 \mathrm{~g} / \mathrm{t}$; the No. 16 orebody found in the P3-H6 abnormal area, the total length of the gold orebody controlled strike was $160 \mathrm{~m}$, the dip length was 83 174 m, the average thickness was $1.96 \sim 4.07 \mathrm{~m}$, and the average Au grade was $6.10 \mathrm{~g} / \mathrm{t}$. Several completed bore holes (ZK01-ZK15) were drilled, and corresponding gold bodies were found (Figure 7). It was verified that the deep features of the abnormal areas of P1-H1 and P3-H6 accorded with the results of the AMT measurement. This indicates that the gold orebody in the study area extended downward along the fault zone, and there may be industrial-grade concealed orebody (mineralization) in the depth.
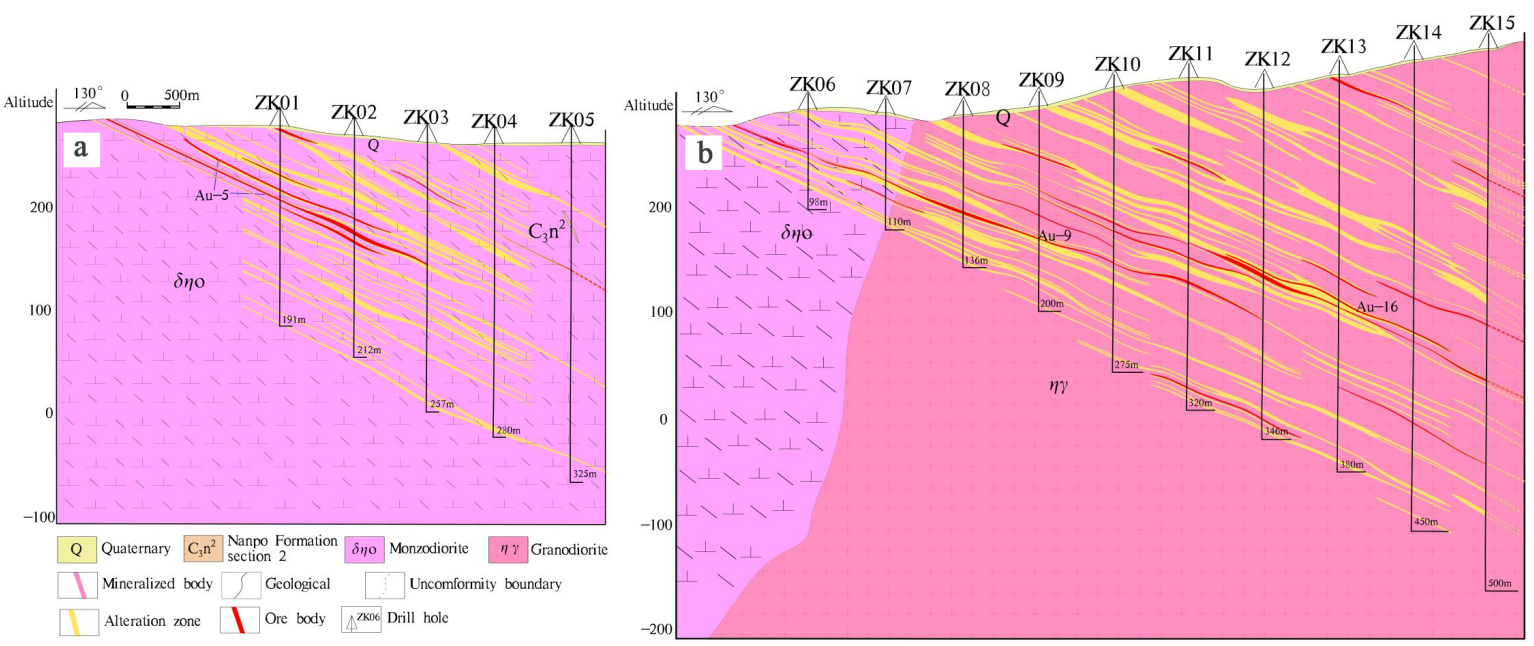

Figure 7. Prospecting profile of the drill hole verifying the anomalies, showing the revealed $\mathrm{Au}$ mineralization in the Nanpo deposit: (a) 111 line borehole profile; (b) 191 line borehole profile.

\section{Discussion}

\subsection{Indicators for Geophysical and Geochemical Prospecting}

According to the distribution of geochemical anomalies, metallogenic geological conditions, and distribution characteristics of known minerals in the study area, it was found that $\mathrm{Au}, \mathrm{Ag}, \mathrm{Cu}$, and other metallogenic elements related to hydrothermal sulfide in the Nanpo gold deposit were mainly enriched in intermediate acid magmatic rocks, while IP anomalies corresponded well with geochemical anomalies. The physical characteristics of rock (ore) specimens showed that the ore (pyrite and pyritized magmatic rock) mainly showed the characteristics of medium-low resistance and medium-high polarization. By comparing the known orebody with the inversion resistivity section of AMT, it can be found that the ore body was mainly located in the relatively low-resistance anomaly in the high-resistivity horizon, especially in the position with high-resistivity layer thickness, local anomaly distortion, sudden decrease in resistivity, and high amplitude frequency. This is consistent with the characteristics that ore bodies in the study area mainly occur in magmatic rocks (high-resistance rock masses), and when ore bodies are enriched in the rock masses, the resistivity will decrease, the apparent amplitude frequency will increase, and the local characteristics are of relatively low-resistance and high-polarization anomaly. Therefore, a comprehensive prospecting indicator for the study of geophysical and geochemical exploration in the mining area was determined: A large-scale and highly overlapping $\mathrm{Au}-\mathrm{Ag}-\mathrm{Cu}$ anomaly area appears in felsic magmatic rocks; at the same time, the area where the apparent resistivity suddenly decreases and the apparent amplitude frequency is relatively high is the most favorable ore-forming area. 


\subsection{Causes of Geophysical and Geochemical Exploration Anomalies}

According to the regional geological background and mineralization characteristics of the study area, we have explained the main causes of soil geochemical anomalies: (I) The background values of $\mathrm{Au}-\mathrm{Ag}-\mathrm{Cu}-\mathrm{Fe}$ and other metallogenic elements are highly in the Nanpo Formation Section 2 strata $\left(\mathrm{C}_{3} \mathrm{n}^{2}\right)$; (II) the dense brittle-ductile shear zones, secondary fracture and fissure zones become the fluid migration paths connecting regional tectonic-magmatic-hydrothermal activities [43-52]. With the migration of ore-bearing hydrothermal solution, a strong water-rock reaction occurs with the wall rock, which is characterized by alteration phenomena such as silicification, carbonation, chloritization, potash feldspathization, clayization, sericitization, and $\mathrm{Au}-\mathrm{Ag}-\mathrm{Cu}-\mathrm{Fe}$ ore (mineralized) bodies filled with rocks and fissures in fine reticulate vein, irregular clumpy, and veined manner (different thickness). (III) The dispersion, migration, and secondary enrichment of these elements on the surface or in the shallow underground are conducive to the formation of super anomalies in the whole deposit district.

Similarly, the causes of geophysical anomalies may be as follows: (I) frequent tectonic activities in the district lead to the development of faults and structural fracture zones as well as the development of associated shear-tensile joints and fissures, which provide good ore-guiding and ore-hosting space for mineralization (Figure 2); (II) in the later stages, affected by regional uplift-denudation and other factors, the oxidation-leaching process on the surface and in the shallow underground promoted the in situ dispersion and local epigenetic enrichment of $\mathrm{Au}-\mathrm{Ag}-\mathrm{Cu}-\mathrm{Fe}$ and other elements to form anomaly belts with medium and low resistivity and medium and high polarization distributed along the intermediate acid magmatic rock mass and its fault zone (Figure 6).

\subsection{Mineralization Model of the Nanpo Deposit}

According to the regional background and geological characteristics of the Nanpo deposit, including the relationship between mineralogy, structure, and tectonics of ore minerals, the generation sequence of metallic minerals is as follows: magnetite $\rightarrow$ ilmenite $\rightarrow$ hematite $\rightarrow$ pyrite $\rightarrow$ chalcopyrite $\rightarrow$ chalcocite. Previous studies have shown that Au$\mathrm{Ag}-\mathrm{Cu}$ and other ore-forming elements related to hydrothermal sulfides in the Nanpo gold deposit area are relatively high in Indosinian intermediate acid magmatic rocks, and most of the element deviations are also large. In addition, there are reddish-brown or yellowishbrown iron spots (limonitization) distributed in the fissures of the rock stratum, which are locally in the form of sand, crust, and lump, and they are the products of secondary leaching and weathering of pyrite and other iron-bearing minerals. Therefore, combined with the characteristics of major and trace elements, rare earth elements and the zircon $\mathrm{U}-\mathrm{Pb}$ age (248 Ma) of felsic magmatic rocks in the Nanpo gold deposit, it was inferred that the mineralization may be related to the arc volcanic magma formed by the continuous eastward subduction of the Paleo-Tethys Ocean in the Early Triassic.

Therefore, a conceptual metallogenic model was proposed to describe the metallogenic process: From the Late Carboniferous to Middle Permian, the Suketai block escaped from the Indosinian plate due to the subduction of the Paleo-Tethys Ocean Basin to the West, forming the Nan-Uttaradit back-arc basin. A series of arc-type Calc-alkaline volcanicintrusive rocks and a series of NE-SW trending brittle-ductile fault systems (tectonic fracture zones) were developed in the Phongsali-Ballay-Loei area, which provided migration channels for ore-bearing hydrothermal fluids. Due to the low temperature and fast subduction speed of the subducted oceanic crust, the temperature of the oceanic crust had no time to adjust to the high-temperature range of the surrounding mantle. The strong temperature and pressure changes led to dehydration and decarbonization to produce metamorphic fluid and may have mixed the deep magmatic fluid to form the initial ore-forming fluid.

During the Late Permian-Early Triassic, the back-arc basin of the Nan-Uttaradit began to subduct to the East, which resulted in the lithospheric delamination and thinning, the generation or activation of deep and large faults, and the formation of the Luang Prabang 
fault and the Preshan fault. With the upwelling of the asthenosphere mantle magma, the thickening lower crust formed. The conclusion that the origin of the felsic pluton in the Nanpo gold deposit originated from the partial melting of the thickened lower crust material can prove that the Luang Prabang-Loei tectonic belt experienced a continental crust thickening event during this period (details will be published separately). With continuous subduction, the material of the deep asthenosphere is strongly upwelling, which further generates a large amount of heat energy and leads to the crust remelting, forming a mixed fluid of crust and mantle. Large-scale magmatic intrusion makes the lithospheric mantle continuously depleted and thinned, resulting in the removal of metallogenetic elements ( $\mathrm{Au}, \mathrm{Ag}$, and others) from the upper mantle and their upward migration through the mantle plume. In the process of ascending, the ore-bearing fluid reacts strongly with the wall rock to extract the ore-forming materials. Due to the change in tectonic properties (Ductile $\rightarrow$ Ductile-brittle $\rightarrow$ Brittle) and physicochemical conditions, the metamorphic fluid rich in gold and other minerals is immiscible and phase-separate from the post-felsic magmatic-hydrothermal solution in the mining area, resulting in the precipitation and enrichment of ore-forming materials in the structural fracture alteration zone formed in the early stage (Figure 8). This model provides new insights for the metallogenic research and exploration of the Nanpo deposit and the entire Luang Prabang-Loei island arc belt.

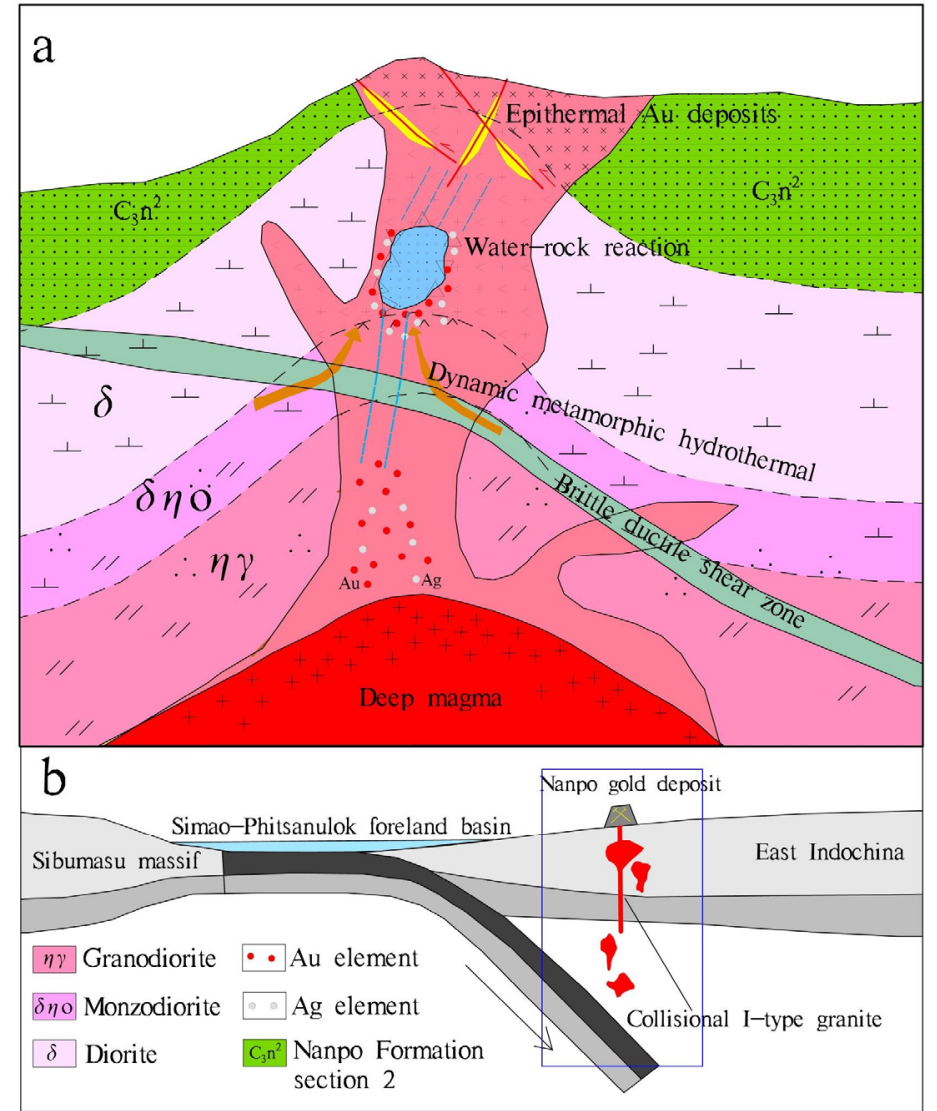

Figure 8. (a) Generalized mineralization model of the Nanpo gold deposit in the Luang Prabang-Loei island arc belt of Laos; (b) sketched map of Indosinian volcanism caused by eastward subduction of the Paleo-Tethys Ocean (modified from [13-21,34,43]).

\section{Conclusions}

Soil geochemical survey, IP intermediate gradient scanning, audio geodesy were carried out successively in the Nanpo gold deposit, and several achievements were attained by the different working methods. 
(1) The Nanpo gold deposit occurs in the Indosinian felsic magmatic rock mass in the Luang Prabang-Loei island arc belt in northwest Laos. Moreover, the gold ore (mineralized) bodies showed characteristics of low resistance and high polarization, which was obviously different from the characteristics of high resistance and low polarization of the surrounding rock. Thus, it has the prerequisite for electromagnetic exploration;

(2) Large-scale and overlapping comprehensive anomalies were identified, and concealed ore (mineralization) bodies were delineated in the deep by audio geodetic survey. The P1-H1 and P3-H6 anomalies were verified by drilling in the extension area around the known mining area, and the expected gold (mineralized) bodies were found;

(3) From the statistical results of the main metallogenic elements enriched in each stratigraphic region of the research area, contents of $\mathrm{Au}, \mathrm{Ag}$, and $\mathrm{Cu}$ related to hydrothermal sulfide were high in the Upper Carboniferous Nanpo Formation Section $2 \operatorname{strata}\left(C_{3} n^{2}\right)$, and most of the elements had large deviations. This is consistent with the fact that the known ore (mineralized) points mostly occurred on this horizon, which is the most promising horizon in the area;

(4) According to the research on the geological, physical, and geochemical prospecting characteristics of the Nanpo gold deposit as well as the subsequent exploration results, it was also verified that there may be hidden ore bodies in the area, which have good prospecting potential. At the same time, the geophysical and geochemical anomaly characteristics and prospecting experience in the study area can provide reference for the search for structurally altered rock-type gold deposits and related quartz-vein-type hydrothermal copper-gold polymetallic deposits in the Luang Prabang arc zone.

Author Contributions: J.G., Z.H., and H.L. (Hui Li) designed the project; J.G. and H.L. (Huan Liu) conducted the original literature reviews; J.M. and L.W. performed the field geological survey; J.G. and Z.H. wrote and organized the paper with a careful discussion and revision by Y.G. All authors have read and agreed to the published version of the manuscript.

Funding: This research was funded by the China Geological Survey Project, grant No. 1212011120337.

Acknowledgments: Thanks is given for the support of Laos Dynamics Mining Co., Ltd. We also thank the geochemical exploration team and 403 geological team of the Sichuan Provincial Bureau of Geology and Mineral Resources for their field technical support.

Conflicts of Interest: The authors declare no conflict of interest.

\section{References}

1. Fon, A.N.; Che, V.B.; Suh, C.E. Application of Electrical Resistivity and Chargeability Data on a GIS Platform in Delineating Auriferous Structures in a Deeply Weathered Lateritic Terrain, Eastern Cameroon. Int. J. Geosci. 2012, 3, 960-971. [CrossRef]

2. Weatherley, D.K.; Henley, R.W. Flash vaporization during earthquakes evidenced by gold deposits. Nat. Geosci. 2013, 6, $294-298$. [CrossRef]

3. Goldfarb, R.J.; Taylor, R.D.; Collins, G.S.; Goryachev, N.A.; Orlandini, O.F. Phanerozoic continental growth and gold metallogeny of Asia. Gondwana Res. 2014, 25, 48-102. [CrossRef]

4. Shi, M.; Lin, F.; Fan, W.; Deng, Q.; Cong, F.; Tran, M.; Zhu, H.; Wang, H. Zircon U-Pb ages and geochemistry of granitoids in the Truong Son terrane, Vietnam: Tectonic and metallogenic implications. J. Asian Earth Sci. 2015, 101, 101-120. [CrossRef]

5. Qian, X.; Feng, Q.; Wang, Y.; Chonglakmani, C.; Monjai, D. Geochronological and geochemical constraints on the mafic rocks along the Luang Prabang zone: Carboniferous back-arc setting in northwest Laos. Lithos 2016, 245, 60-75. [CrossRef]

6. Rossignol, C.; Bourquin, S.; Poujol, M.; Hallot, E.; Dabard, M.-P.; Nalpas, T. The volcaniclastic series from the Luang Prabang Basin, Laos: A witness of a triassic magmatic arc? J. Asian Earth Sci. 2016, 120, 159-183. [CrossRef]

7. Zaw, K.; Meffre, S.; Lai, C.; Burrett, C.; Santosh, M.; Graham, I.; Manaka, T.; Salam, A.; Kamvong, T.; Cromie, P. Tectonics and metallogeny of mainland Southeast Asia-A review and contribution. Gondwana Res. 2014, 26, 5-30.

8. Xue, Y.; Li, X.; Zhou, W. Geological and geochemical characteristics and prospecting prediction of huailiang gold deposit in Bawu County, Laos. Met. Mine 2021, 03, 153-163. (In Chinese)

9. Chen, X.; Zhao, Y.; Zhang, Q.; Dong, A.; Hu q Bai, L.; Wu, J. Sources of ore forming fluids and metals of the Pangkuam Cu-Au deposit, Laos:evidence from H-O-He-Ar-C-S-Pb isotopes. Acta Geol. Sin. 2021, 95, 476-492. (In Chinese)

10. Cai, G.; An, F. A review on the geological setting, geochemical characteristics and metallogenic model of orogenic gold deposits. Geol. Sci. Technol. Inf. 2018, 37, 163-172. (In Chinese) 
11. Zhao, Y.-P.; Kang, T.-S.; Ning, G.-C.; Ge, H.; Pan, H. Geochemical characteristics of the volcanic intrusive complex in the Pangkuam copper-gold deposit of Laos and its geological significance. Acta Petrol. Mineral. 2017, 36, 281-294. (In Chinese)

12. Xia, Y.; Zhou, W.; Shan, Z. Study on technological characteristics of copper gold ore in a deposit in bankangm, Laos. Geol. Explor. 2017, 53, 198-206. (In Chinese)

13. Shi, M.; Khin, Z.; Liu, S.; Xu, B.; Meffre, S.; Cong, F.; Nie, F.; Peng, Z.; Wu, Z. Geochronology and petrogenesis of Carboniferous and Triassic volcanic rocks in NW Laos: Implications for the tectonic evolution of the Loei Fold Belt. J. Asian Earth Sci. 2021, 208, 104661. [CrossRef]

14. Yang, W.; Qian, X.; Feng, Q.; Shen, S.; Chonglakmani, C. Zircon U-Pb geochronological evidence for the evolution of the Nan-Uttaradit suture in northern Thailand. J. Earth Sci.-China 2016, 27, 378-390. [CrossRef]

15. Hou, L.; Liu, S.; Guo, L.; Xiong, F.; Li, C.; Shi, M.; Zhang, Q.; Xu, S.; Wu, S. Geology, Geochronology, and Hf Isotopic Composition of the Pha Lek Fe Deposit, Northern Laos: Implications for Early Permian Subduction-Related Skarn Fe Mineralization in the Truong Son Belt. J. Earth Sci.-China 2019, 30, 109-120. [CrossRef]

16. Niu, Y.-J.; Hu, J.; Li, X.-H. Study on the Geochemical Features of the Phabon Gold Deposit, Laos. Geol. Surv. Res. 2013, 36, 92-99. (In Chinese)

17. Sibson, R.H.; Scott, J. Stress / fault controls on the containment and release of overpressured fluids: Examples from gold-quartz vein systems in Juneau, Alaska; Victoria, Australia and Otago, New Zealand. Ore Geol. Rev. 1998, 13, 293-306. [CrossRef]

18. Laznicka, P. Giant Metallic Deposits; Springer: Berlin/Heidelberg, Germany, 2010.

19. Liu, S.; Fan, W.; Luo, M.; Tang, F.; Zhu, H.; Chen, W. Zircon U-Pb dating and petrogeochemical characteristics of bimodal volcanic rocks in paletong, southern Laos. Journal of Jilin University: Earth Sci. Ed. 2014, 44, 540-553.

20. Nie, F.; Liu, S.S.; Yang, Y.F.; Peng, Z.; Guo, L. Zircon U-Pb Dating and Its Geological Implication for the Diorites from the Phu Lon Skarn-Type Copper-Gold Deposit in Thailand. Sediment. Geol. Tethyan Geol. 2019, 39, 71-78.

21. Guo, L.N.; Hou, L.; Liu, S.S.; Nie, F. REE geochemistry and C-O isotope characteristics of hydrothermal calcites: Implications for fluid-rock reaction and ore-forming processes in the Phapon gold deposit, NW Laos. Minerals 2018, 8, 438. [CrossRef]

22. Liu, J.; Zhao, G.; Xu, G.; Sha, D.; Xiao, C.; Fang, X.; Liu, F.; Guo, Q.; Yu, H. Structural control and genesis of gold deposits in the Liaodong Peninsula, northeastern North China Craton. Ore Geol. Rev. 2020, 125, 103672. [CrossRef]

23. Metcalfe, I.; Crowley, J.L. Upper Permian and Lower Triassic conodonts, high-precision U-Pb zircon ages and the Permian-Triassic boundary in the Malay Peninsula. J. Asian Earth Sci. 2020, 199, 104403. [CrossRef]

24. Metcalfe, I. Gondwana dispersion and Asian accretion: Tectonic and palaeogeographic evolution of eastern Tethys. J. Asian Earth Sci. 2013, 66, 1-33. [CrossRef]

25. Sone, M.; Metcalfe, I.; Chaodumrong, P. The Chanthaburi terrane of southeastern Thailand: Stratigraphic confirmation as a disrupted segment of the Sukhothai Arc. J. Asian Earth Sci. 2012, 61, 16-32. [CrossRef]

26. Hou, L.; Xiong, F.; Wang, W.; Guo, L.; Peng, H.; Ni, S.; Zhang, Q. Carboniferous-Triassic felsic igneous rocks and typical mineral deposits in the Truong Son orogenic belt, SE Asia: Implications for Paleo-Tethyan tectonic evolution and metallogeny. Ore Geol. Rev. 2019, 112, 103036. [CrossRef]

27. Wu, S.; Nie, F.; Liu, S.; Xie, E.; Leng, Q.; Li, Y.; Wu, Z.; Zhang, H. The Discovery of Ophiolitic Complex in Namhonr, Northern Loei Tectonic Belt and Its Geological Significance. Earth Sci. 2021, 1-31.

28. Lu, F.F.; Yang, H.L.; Tong, W.H.; Zhao, M.S. Inclusion characteristics of Phabon gold deposit, Laos. Henan Sci. 2015, 33, 1985-1989.

29. Hara, H.; Tokiwa, T.; Kurihara, T.; Charoentitirat, T.; Ngamnithiporn, A.; Visetnat, K.; Tominaga, K.; Kamata, Y.; Ueno, K. Permian-Triassic back-arc basin development in response to Paleo-Tethys subduction, Sa Kaeo-Chanthaburi area in Southeastern Thailand. Gondwana Res. 2018, 64, 50-66. [CrossRef]

30. Shifeng, W.; Yasi, M.; Chao, W.; Peisheng, Y. Paleotethyan evolution of the Indochina Block as deduced from granites in northern Laos. Gondwana Res. 2016, 38, 183-196.

31. Wang, H. Study on Tectonic Evolution and Mineralization in Laos and Its Adjacent Areas. Ph.D. Thesis, University of Chinese Academy of Sciences, Beijing, China, 2013. (In Chinese).

32. Li, H. Metallogenic Model and Primary Halo Prospecting Model of Papen Gold Deposit in Laos. Master's Thesis, China University of Geosciences, Beijing, China, 2014. (In Chinese).

33. Khamsone, L. Geological Characteristics and Prospecting Criteria of Lalang Gold Deposit in Mengkan County, Xieng Khouang Province, Laos. Master's Thesis, Kunming University of Technology, Kunming, China, 2018. (In Chinese).

34. Zou, H.; Han, R.; Liu, M.; Cromie, P.; Zaw, K.; Fang, W.; Huang, J.; Ren, T.; Wu, J. Geological, geophysical, and geochemical characteristics of the Ban Kiouchep Cu-Pb-Ag deposit and its exploration significance in Northern Laos. Ore Geol. Rev. 2020, 124, 103603. [CrossRef]

35. Zhang, Y.; Wang, Y.; Srithai, B.; Phajuy, B. Petrogenesis for the Chiang Dao Permian high-iron basalt and its implication on the Paleotethyan Ocean in NW Thailand. J. Earth Sci.-China. 2016, 27, 425-434. [CrossRef]

36. Phillips, G.N.; Powell, R. Hydrothermal alteration in the Witwatersrand goldfields. Ore Geol. Rev. 2015, 65, 245-273. [CrossRef]

37. Iles, K.A.; Hergt, J.M.; Sircombe, K.N.; Woodhead, J.D.; Bodorkos, S.; Williams, I.S. Portrait of a reference material: Zircon production in the Middledale Gabbroic Diorite, Australia, and its implications for the TEMORA standard. Chem. Geol. 2015, 402, 140-152. [CrossRef]

38. Yang, Q.; Santosh, M.; Shen, J.; Li, S. Juvenile vs. recycled crust in NE China: Zircon U-Pb geochronology, Hf isotope and an integrated model for Mesozoic gold mineralization in the Jiaodong Peninsula. Gondwana Res. 2014, 25, 1445-1468. [CrossRef] 
39. Liu, S. Study on Tectonic Magmatic Mineralization of Luang Prabang, Laos Lifu Copper Gold Metallogenic Belt, Thailand. Ph.D. Thesis, Chengdu University of Technology, Chengdu, China, 2021. (In Chinese).

40. Xin, Q. Tectonic Evolution of Ancient Tethys in Luang Prabang and Lifu Structural Belt, Laos. Ph.D. Thesis, China University of Geosciences, Wuhan, China, 2016. (In Chinese).

41. Qiu, K.F.; Deng, J.; Taylor, R.D.; Song, K.R.; Song, Y.H.; Li, Q.Z.; Goldfarb, R.J. Paleozoic magmatism and porphyry Cumineralization in an evolving tectonic setting in the North Qilian Orogenic Belt, NW China. J. Asian Earth Sci. 2016, 122, 20-40. [CrossRef]

42. Shao, C.L.; Wang, J.S.; Li, Z.J.; Liu, W.J. Study on gold metallogenic belt and mineralization concentrated area of Laos. Miner Explor. 2015, 6, 787-796. (In Chinese)

43. Feng, Q.; Yang, W.; Shen, S.; Chonglakmani, C.; Malila, K. The Permian seamount stratigraphic sequence in Chiang Mai, North Thailand and its tectogeographic significance. Sci. China. Ser. D Earth Sci. 2008, 51, 1768-1775. [CrossRef]

44. Metcalfe, I.; Metcalfe, I.; Shi, G.R. Permian tectonic framework and palaeogeography of SE Asia. J. Asian Earth Sci. 2002, 20, 551-566. [CrossRef]

45. Goldfarb, R.J.; Groves, D.I.; Gardoll, S. Orogenic gold and geologic time: A global synthesis. Ore Geol. Rev. 2001, 18, 1-75. [CrossRef]

46. Kerrich, R.; Goldfarb, R.; Groves, D.; Garwin, S.; Jia, Y. The characteristics, origins, and geodynamic settings of supergiant gold metallogenic provinces. Sci. China. Ser. D Earth Sci. 2000, 43, 1-68. [CrossRef]

47. Groves, D.I.; Goldfarb, R.J.; Knox-Robinson, C.M.; Ojala, J.; Gardoll, S.; Yun, G.Y.; Holyland, P. Late-kinematic timing of orogenic gold deposits and significance for computer-based exploration techniques with emphasis on the Yilgarn Block, Western Australia. Ore Geol. Rev. 2000, 17, 1-38. [CrossRef]

48. Sibson, R.H. Generation of Pseudotachylyte by Ancient Seismic Faulting. Geophys. J. R. Astron. Soc. 1975, 43, 775-794. [CrossRef]

49. Zhao, T.; Qian, X.; Feng, Q. Geochemistry, zircon U-Pb age and Hf isotopic constraints on the petrogenesis of the Silurian rhyolites in the Loei fold belt and their tectonic implications. Earth Sci. 2016, 27, 391-402. [CrossRef]

50. Sun, T.; Chen, F.; Zhong, L.; Liu, W.; Wang, Y. GIS-based mineral prospectivity mapping using machine learning methods: A case study from Tongling ore district, eastern China. Ore Geol. Rev. 2019, 109, 26-49. [CrossRef]

51. Guo, Z.; Hu, L.; Liu, C.; Cao, C.; Liu, J.; Liu, R. Application of the CSAMT Method to Pb-Zn Mineral Deposits: A Case Study in Jianshui, China. Minerals 2019, 9, 726. [CrossRef]

52. Chen, H.; Chen, Y.; Baker, M. Isotopic geochemistry of the Sawayaerdun orogenic-type gold deposit, Tianshan, northwest China: Implications for ore genesis and mineral exploration. Chem. Geol. 2012, 310-311, 1-11. [CrossRef] 